\title{
FALSIFYING PRIORITY OF SPECIES NAMES: A CASE FROM 1892
}

WEISS, Malcolm P., Dept. of Geological Sciences, Preston Cloud Research Laboratory, University of California, Santa Barbara, CA 93106.

A study of Minnesota Ordovician brachiopods (Winchell \& Schuchert [W\&S], 1893) was in preparation during the spring of 1892 . At the same time, a student was preparing to publish his Masters thesis and other papers, including descriptions of new brachiopod species. Fearing that some new species for the forthcoming Final Report of the Minnesota Geological and Natural History Survey (W\&S, 1895) might be thrown into synonymy, N. H. Winchell [NHW] resorted to a phony prepublication device to prevent the student's names from priority.

NHW had E. O. Ulrich [EOU] prepare an article as a preprint of his and Schuchert's [CS] descriptions for a forthcoming issue of THE AMERICAN GEOLOGIST, of which NHW was editor. EOU delivered a preprint (W\&S, 1892a) to the student on 1 April 1892. It was bound and covered, had no figures, but had a printed phrase "Distributed April 1, 1892." The student, F.W. Sardeson [FWS], was told it had been mailed out. It had not been, and the preprint given him was unique.

Printed copies of FWS's work, with figures, arrived on 2 April, and were mailed out 6 April (FWS, 1892). This assured that six of FWS's names were suppressed by those of W\&S (1892a), though the 1 April preprint was soon "withdrawn," because "the authors rejected it." On 21 April, EOU brought FWS another preprint (W\&S, 1892b), saying the first had never been mailed, but that this one would be [it was]. Only a few misprints in the earlier text were corrected and four subgenera were deleted. The cover of the new preprint read "Proofs distributed April 1, 1892" [not true], and that the new form, dated 21 April, was a "corrected reprint." The new text appeared in THE AMERICAN GEOLOGIST, volume 9, that May (W\&S, 1892c). It is possible that CS tried to avoid the fraud, for between 1 and 21 April rumors said he had rejected the 1 April text. He was, however, NHW's employee, and at his mercy.

By this small, cheap act, NHW saved himself editorial trouble and printing cost. He believed his saving was worth more than a mere student's work. Another error, probably clerical, crept in: FWS's names are cited as of 9 April, rather than 6 April.

The fraud was implanted in brachiopod literature when CS, in his "Synopsis" of 1897, gave priority as of 1 April 1892 to W\&S's names. The same synonymies were repeated by Bassler (1915), in his "Bibliography," but he had no complicity in the original fraud. The taxa of FWS (1892) are now forgotten, but because no preprints were mailed 1 April 1892, his names are valid, by international rules. Other names (W\&S, 1892a) prevail because they have been so oft-repeated in the literature.

FWS 6 April 1892

Orthis minnesotensis

O. petrae

Rhynchonella sancta

Streptorhynchus subsulcatum

Strophomena halli

Zygospira aquila
W\&S 21 April 1892

O. meedsi

O. proavita

Rhynchotrema inaequivalvis var. laticosta

Strophomena scofieldi

Leptaena charlottae

Hallina nicolleti 